\title{
Feeding habits of young predatory fishes in marsh creeks situated along the salinity gradient of the Schelde estuary, Belgium and The Netherlands
}

Received: 13 April 2004/ Revised: 9 December 2004/ Accepted: 10 December 2004/Published online: 17 February 2005

(C) Springer-Verlag and AWI 2005

\begin{abstract}
Fish and macrobenthos were sampled in four different marshes along the salinity gradient of the Schelde estuary, Belgium/Netherlands, to investigate the importance of marsh creeks as foraging grounds for the dominant, larger fish species. The total density and biomass of all the main macrobenthic taxa (Corophium volutator, Nereis diversicolor, Oligochaeta, Macoma baltica and Heteromastus fliliformis) were measured. The feeding habits of the larger predatory fishes (Platichthys flesus, Dicentrarchus labrax) were investigated. Qualitative and quantitative stomach analyses included the calculation of different indices, showing the niche breadth (as diet diversity) and the niche overlap (as similarity between the predators' diet) for this habitat. These analyses showed that the two most important benthic prey species for $P$. flesus were $C$. volutator and $N$. diversicolor. D. labrax preyed upon a wider range of species, including $C$. volutator, $N$. diversicolor, Crangon crangon, Carcinus maenas and Orchestia spp. The stomach diversity of D. labrax and P. flesus showed differences between the marshes although there was no consistent pattern in diet composition, reflecting the opportunistic nature of feeding by these large predators. The fullness indices of both flounder and sea bass did not differ significantly along the salinity gradient and the
\end{abstract}

Communicated by H.-D. Franke

\footnotetext{
H. Hampel $(\bowtie)$

Department of Biology, Marine Biology Section, University of Gent, Krijgslaan 281, S8, 9000 Gent, Belgium

E-mail: hhampel@naturalsciences.be

Tel.: + 32-9-2648524

A. Cattrijsse

Flemish Marine Institute, VLIZ (Vlaams Instituut van de Zee), Vismijn, Pakhuizen 45-52, Oostende, 8400, Belgium

E-mail: andre.cattrijsse@vliz.be

M. Elliott

Institute of Estuarine and Coastal Studies,

University of Hull, Hull, HU6 7RX, UK

E-mail: Mike.Elliott@hull.ac.uk
}

estimated minimum consumption by these predators did not indicate a top-down control of the macrobenthic community. The salt marsh creeks seem to provide excess food for the visiting fish species. The benthic prey was present in very high abundances, which may suggest that the typical nursery species such as $C$. crangon and C. maenas, and early juveniles of $P$. flesus, D. labrax and Pomatoschistus microps were not preyed upon significantly. This supports the hypothesis that salt marsh creeks provide good refuge areas for nursery species against predation by larger fish.

Keywords Feeding habit - Salinity gradient

Salt marsh $\cdot$ Predatory fish

\section{Introduction}

The lifecycles of many coastal fish species are closely associated with estuaries, lagoons, tidal flats and salt marshes (Hostens and Mees 1999; Laffaille et al. 2001b). In several parts of the US (Dionne et al. 1999; Rozas and Zimmerman 2000) and also in Europe (Lefeuvre et al. 2000; Costa et al. 2001), fish utilise salt marshes as nursery areas which offer protection (Paterson and Whitfield 2000) and food (Rozas and Odum 1988) for the visiting species. Several species perform tidal feeding migrations from estuaries into the tidal marsh creeks, where they find abundant potential prey items (Raffaelli et al. 1990; Elliott and Hemingway 2002). The energy expenditure involved in these movements is assumed to be compensated by the high abundance and biomass of the available invertebrate prey (Wolff et al. 1981) and Gibson (1994) suggested that food is probably the major factor determining habitat quality.

In predator-prey relationships, the abundance of predator and prey can be regulated by top-down and bottom-up control, respectively. In subtidal areas, studies have reported reduced densities of benthic invertebrates when nekton became seasonally abundant 
(Wiltse et al. 1984). In tidal marshes, the foraging time is limited by tidal inundation but marsh nekton may still affect the abundance of invertebrates (Kneib 1995), the dynamics of individual prey populations (Joyce and Weisberg 1986) and the community composition of both benthic (Frid and James 1988) and epibenthic prey (Walters et al. 1996). In contrast, prey densities may restrict the abundance of predators in a habitat, i.e. by bottom-up control. The density of juveniles present in a habitat reflects recruitment, mortality and emigration and can thus be an important indicator of nursery value of that habitat (Minello et al. 2003). These features were shown, for example, by Cattrijsse et al. (1994) with regard to the importance of tidal marshes in the Schelde estuary as nurseries for estuarine fish species. However, two large predatory fishes, the flounder Platichthys flesus and the sea bass Dicentrarchus labrax, were found to occur in the salt marsh creeks in such high numbers that their occurrence questions the refuge function of this habitat.

In order to interpret the functioning of an estuarine habitat and to analyse food webs, it is necessary to consider prey availability (Elliott et al. 2002). Food availability varies with many factors, both biotic and abiotic, including tidal inundation, thus indicating the difficulty of analysing food webs even in species-poor areas (Gorman and Raffaelli 1993). For example, macrobenthos contribute significantly to the diet of the flounder and sea bass (Laffaille et al. 2001a), and although the feeding habits and diet composition of young flounder and sea bass have been studied in estuaries and coastal waters (Aarnio et al. 1996; Aarnio and Bonsdorff 1997), there are only a few studies of the feeding dynamics in salt marshes (Laffaille et al. 2000, 2001b).

The present study aims to examine the spatial variability in the feeding habit of P. flesus and D. labrax through qualitative and quantitative stomach analyses in salt marshes situated along the salinity gradient of the Schelde estuary. A further aim was to assess the benthic food availability for larger sea bass and flounder in marsh creeks. Finally, the study aimed to define the relative importance and impact of $P$. flesus and D. labrax as predators on the infauna and on the nursery/ refuge function of the creeks for juvenile fish and crustaceans.

\section{Materials and methods}

\section{Study area}

Four marshes were chosen along the salinity gradient of the Schelde estuary to investigate the feeding habit of young predator fish species (Fig. 1). The Zwin ( $\mathrm{Zw}$ ) is situated at the mouth of the estuary, in the euhaline zone, and has a total surface area of 125 ha. The Zuidgors ( $Z$ ) marsh belongs to the polyhaline zone of the estuary, and the marsh of Waarde (W) to the mesohaline part. The total surface area of these two marshes

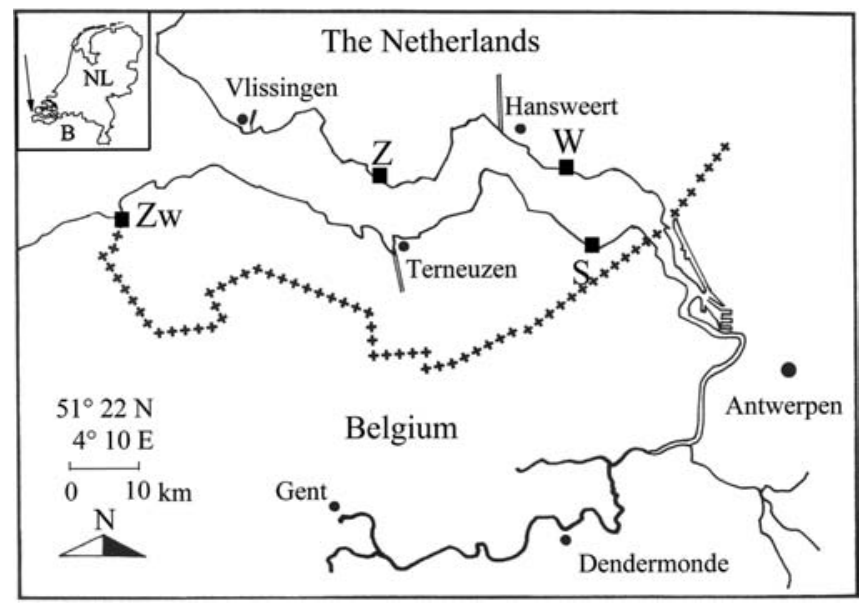

Fig. 1 Location of the four marshes sampled along the Schelde estuary. Letters indicate the marshes Saeftinghe $(S)$, Waarde $(W)$, Zuidgors $(Z)$ and Zwin $(Z w)$

are 50 ha and 107 ha, respectively. 'Het Verdronken Land van Saeftinghe' (S) (2078 ha) also lies in the mesohaline part of the Schelde estuary but has lower salinity than Waarde. The inundation period was $6 \mathrm{~h}$ in the three more upstream marshes, while in Zwin the tide receded within $5 \mathrm{~h}$.

\section{Sampling of fish}

The marshes were sampled on consecutive days during the spring tide period between April and October 2000 for fish, and between May and October 2000 for macrobenthos. Samples were taken every 6 weeks, although Waarde was not sampled in April, and in each marsh, two channels were sampled for fish. Large intertidal channels, which varied between 10-20 $\mathrm{m}$ in width and 3$4 \mathrm{~m}$ in depth, were sampled using fyke nets (details in Elliott and Hemingway 2002) to capture larger fish species. The fyke nets had an opening of $1 \mathrm{~m}$ and a mesh size of $15 \times 15 \mathrm{~mm}$, were $5 \mathrm{~m}$ long and contained six parlours, and at the mouth two $3 \mathrm{~m}$-long wings enlarged the sampling area of each net. The fyke nets were set before water entered the system and faced the outgoing ebb currents to sample fish leaving the creek with the ebb. The fish were collected immediately after the water receded.

Smaller intertidal creeks higher up the marsh were sampled using a block net. These smaller creeks were generally $2 \mathrm{~m}$ wide and $1.5-1.8 \mathrm{~m}$ deep and opened into the larger creeks. The block net was constructed from $5 \mathrm{~mm}$ mesh and had two lateral wings of $2 \mathrm{~m}$ and a central bag. The whole net was $2 \mathrm{~m}$ high with a floated topline, and a ground rope was fitted with a heavy chain. The block net was set at high water near the mouth of the creek. The chain in the ground rope was manually placed on the bottom of the creek and sticks kept the net and ground rope in place. The net contents were recovered after the tide had ebbed. 
Catches were counted and expressed as numbers caught during the ebb period. P. flesus and D. labrax were the two main predator fishes occurring in relative high numbers in the creeks; therefore the stomach analysis focused on these two species.

In the field, all the fishes were anaesthetised in a benzocaine (ethyl amino-4-benzoate)-water solution to prevent regurgitation of the stomach contents, and preserved in formaline solution (approximately 8\%). In the laboratory, the total length of each captured fish was recorded. All prey items in the stomachs were counted, identified, if possible to species level, and the length of each prey item was measured. The biomass (ash-free dry weight $=\mathrm{ADW}$ ) of each prey item present in the stomachs was computed from pre-defined length-ADW regressions and was used to calculate the gravimetric percentages (Hamerlynck and Cattrijsse 1994; Beyst et al. 1999). Stomach contents were placed in preweighed aluminium foil cups, dried at $110^{\circ} \mathrm{C}$ for $2 \mathrm{~h}$, and then samples were placed in pre-weighed ceramic dishes and ashed at $550^{\circ} \mathrm{C}$ for $15 \mathrm{~min}$ to obtain the ash-free dry weight. The AWD was used to calculate stomach fullness index.

\section{Stomach content analysis}

For the quantitative analysis of the stomach contents, the fullness index (FI) was used: $\mathrm{FI}=\left(S_{i} / W_{i}\right) \times 100$, where $S_{i}$ is the ADW of the stomach contents in mg, and $W_{i}$ is the ADW of the fish in mg. The ADW of fish was calculated as $80 \%$ of WW (wet weight of the fish). Total length (TL) of individuals was measured and lengthWW regressions were used to calculate WW. For $P$. flesus the regression was $(\ln \mathrm{WW}=-11.051+2.926 \ln$ TL) and for D. labrax (ln WW $=-11.749+3.061 \ln \mathrm{TL})$.

As a measure of diet diversity and thus niche-breadth (Marshall and Elliott 1997), the Shannon-Wiener index $\left(\mathrm{H}^{\prime}\right)$ of the stomach contents of P. Alesus and D. labrax was calculated for each marsh and month $\mathrm{H}^{\prime}=-\sum p_{i} \times \ln p_{i}$, where $p_{i}$ is the proportion of the individuals found in the $i$ th species.

Three percentages (frequency of occurrence, numerical and gravimetric percentages) were calculated to characterise the stomach content of the fish and to calculate the main food index (MFI). Each of the three indices has its own meaning and limits (Hyslop 1980). The frequency of occurrence $(\mathrm{FO} \%)$ calculates the percentage of the total number of stomachs in which the particular prey species occur: $\mathrm{FO} \%=\left(\mathrm{FO}_{i} / \mathrm{FO}_{t}\right) \times 100$, where $\mathrm{FO}_{i}$ is the number of stomachs in which the $i$ th species occurs, and $\mathrm{FO}_{t}$ is the total number of stomachs analysed (Hyslop 1980).

The diet composition was also expressed as a numerical percentage $(N \%)$ :

$$
N \%=\frac{\text { Number of prey type }_{i}}{\text { Total number of prey items ingested }} \times 100,
$$

and as a gravimetric percentage $(G \%)$ (Hyslop 1980):
$G \%=\frac{\text { ADW of prey type }}{\text { Total ADW of the ingested food }} \times 100$.

Following Zander (1982) and Laffaille et al. (2001b), the three indices were synthesised as the MFI, which was calculated for each food item $i$ as

$\mathrm{MFI}_{i}=\sqrt{\frac{G_{i} \% \times\left(N_{i} \%+\mathrm{FO}_{i} \%\right)}{2}}$.

Then the $\mathrm{MFI}_{i}$ of the $i$ th item was expressed as a percentage of the total MFI. Species which had an MFI higher than $10 \%$ were considered important prey item.

\section{Macrobenthic sampling}

Five replicate plastic cores (diameter $6.2 \mathrm{~cm}$ ) were used to sample the macrobenthos from the large and small creek bed to a depth of $15 \mathrm{~cm}$. Samples were preserved in formaline (approximately 8\%). In the laboratory, samples were washed on a sieve of $0.5 \mathrm{~mm}$ and individuals were identified to the lowest possible taxonomic level. Since more than $80 \%$ of the sampled macrobenthic density in Zwin and more than $90 \%$ in the other marshes were composed of Oligochaeta, the amphipod Corophium volutator, the polychaetes Nereis diversicolor and Heteromastus filiformis, and the bivalve Macoma baltica, and because these species were present in the stomach of the fish, the average total macrobenthic densities (ind. $\mathrm{m}^{-2}$ ) and biomass (ADW) of these taxa were estimated for each month and marsh. Oligochaeta, $C$. volutator, $N$. diversicolor and $H$. filiformis from one sample were placed separately on pre-weighed aluminium cups, dried for $2 \mathrm{~h}$ at $110^{\circ} \mathrm{C}$, and then samples were placed in pre-weighed ceramic dishes and ashed at $550^{\circ} \mathrm{C}$ for 15 min to obtain the ash-free dry weight. The ADW of $M$. baltica was determined using a length-ADW regression $(\ln \mathrm{ADW}=-4.249+2.909 \ln L)$, where $L$ is the length of the individual.

In order to calculate the total macrobenthic standing stock available as fish prey, the surface area of the sampled creek was estimated from topographic maps (scale 1:10,000). The surface area of each creek and the average total macrobenthic density and biomass of the five taxa in each month were then used to estimate the biomass stock in the creek.

\section{Statistical analysis}

As the stomach fullness and diversity indices data of P. flesus and D. labrax were not normally distributed, analysis of variance (ANOVA) was not applicable to test differences between the different marshes. Therefore, the non-parametric Kruskal-Wallis test was used. Spearman-Rank correlation coefficients tested the relation- 
ship between the numbers of fish captured and the macrobenthic density and biomass in the marsh creeks.

Macrobenthos was sampled at each occassion immediately after the tide receded. Their density or biomass and the surface of the creek yield the total number or biomass of macrobenthos in one month. Fish preyed upon this available stock for 5-6 h of each flood period. The total minimum consumption of the two predatory fish ( $P$. flesus, D. labrax) was estimated from the available standing stock (Num\%) and biomass (ADW\%) of macrobenthos.
The number of D. labrax captured in Saeftinghe ranged from 8 to 114, in Waarde from 41 to 83, in Zuidgors from 1 to 97 and in Zwin only from 0 to 4 individuals. The highest values were counted in October in Saeftinghe and in August in Waarde, Zuidgors and Zwin.

The length-frequency distribution (Fig. 2) shows that most flounder were between $130 \mathrm{~mm}$ and $250 \mathrm{~mm}$, whereas D. labrax using the marsh creeks ranged between $80-120 \mathrm{~mm}$ and $150-200 \mathrm{~mm}$. Based on the literature, these values represented fishes of ages $1+$ and $2+$ years (Pickett 1989; Cattrijsse and Hampel 2001).

Num $\%=\frac{\text { Total number of macrobenthic prey in all the analysed stomachs of the two fish species }}{\text { Total number of macrobenthos in the creek }} \times 100$,

ADW $\%=\frac{\text { Total biomass of macrobenthic prey in all the analysed stomachs of the two fish species }}{\text { Total biomass of macrobenthos in the creek }} \times 100$.

\section{Results}

Number of fish captured and length-frequency distribution

Platichthys flesus was not found in the euhaline marsh Zwin. The total number of $P$. flesus captured during ebb in the marsh creeks of Saeftinghe ranged from 2 to 35. In Waarde, 9-40 individuals were caught, while in the Zuidgors marsh between 2 and 16 flounder were found in the nets. Higher numbers were caught during the first part of the sampling period and the highest numbers were observed in April in Saeftinghe and in July in Waarde and Zuidgors.
Fullness index and diet diversity

The average FI of $P$. flesus in Saeftinghe ranged from 0.4 in October to 1.66 in May (Fig. 3a). In Waarde, the highest average FI (1.06) was recorded in May and the lowest $(0.27)$ in October. In Zuidgors, the FI reached 1.41 in April and decreased to 0.69 in October. The average stomach fullness of D. labrax in Saeftinghe reached the maximum (2.13) in October and a minimum (1.13) in July (Fig. 3b). The FI was 1.36 and 2.26 in July and 0.84 and 0.69 in October in Waarde and Zuidgors, respectively. Only 2-4 sea bass were captured in Zwin and their FI was high, with a maximum of 3.8 in October.
Fig. 2 Length-frequency distribution of $P$. flesus and D. labrax in the four sampled marshes. Length $(\mathrm{mm})$ is measured as total length

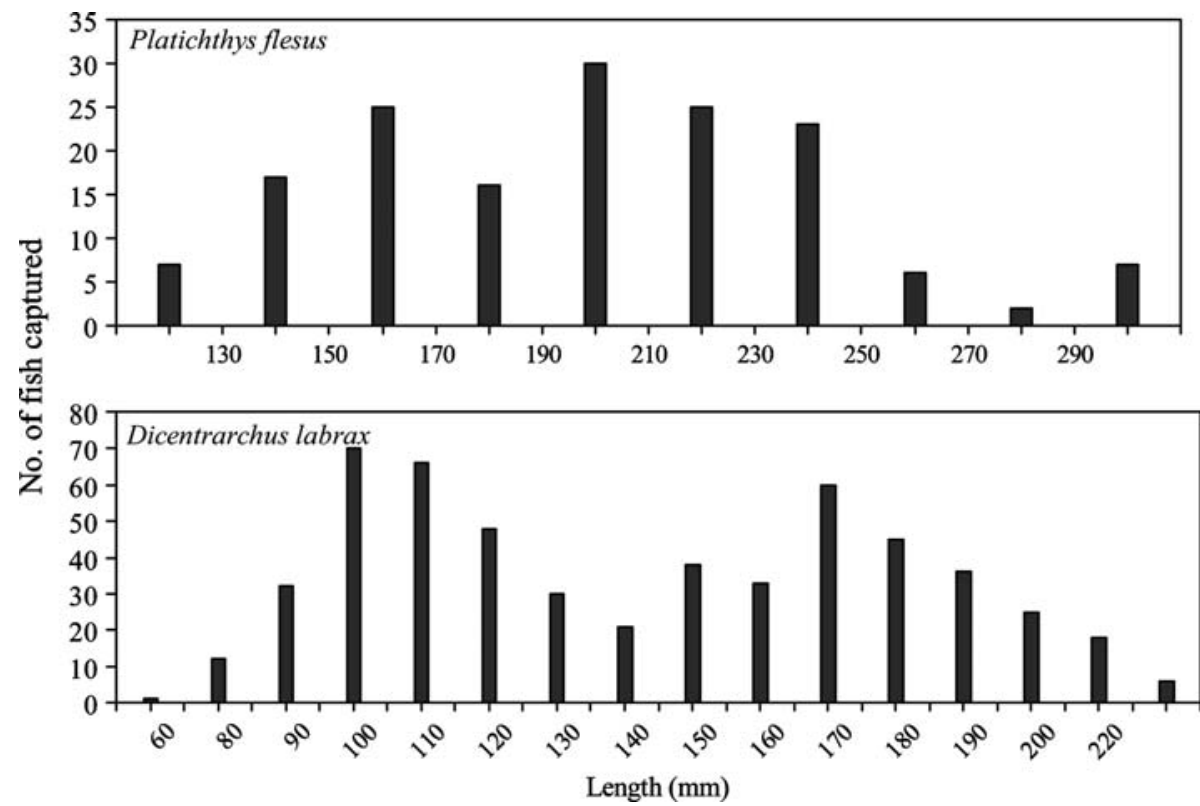


Fig. 3 Fullness index $(F I)$ and Shannon-Wiener diversity index $\left(H^{\prime}\right)$ of Platichthys flesus (a) and Dicentrarchus labrax (b) during the sampling period. Average fullness index and standard error $(S E)$ for each marsh are indicated above the figure
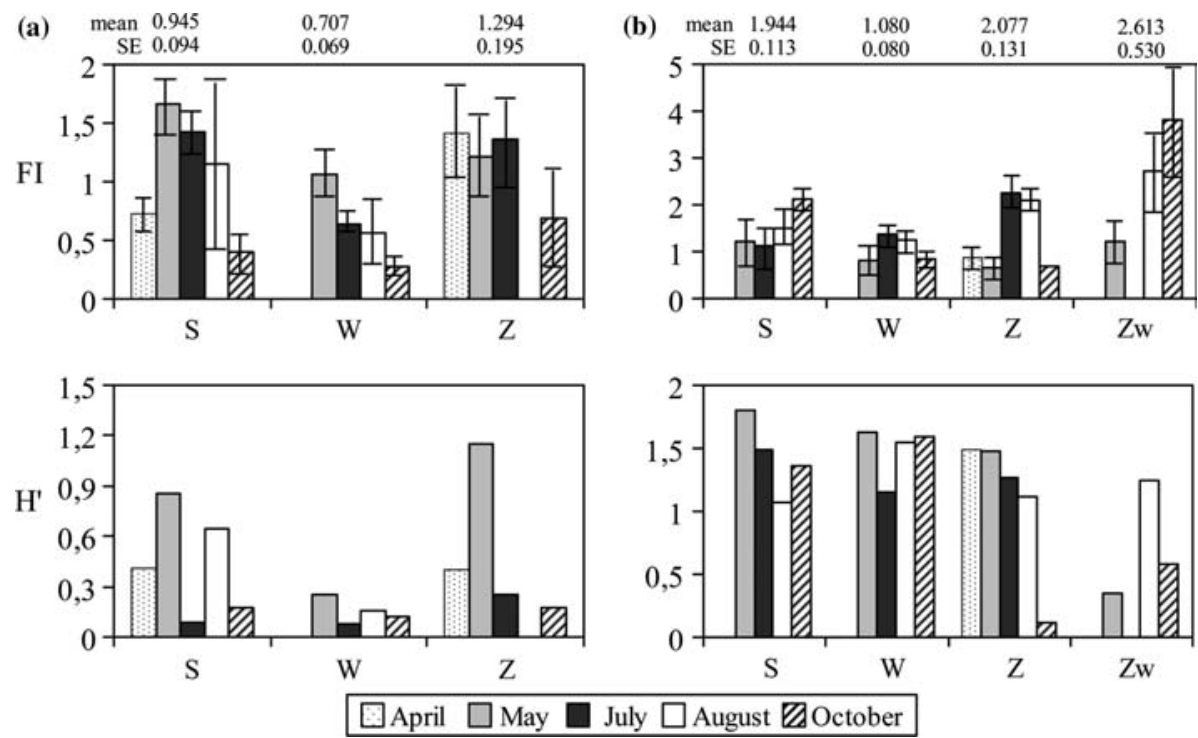

The Shannon-Wiener diversity index of the stomach contents of $P$. flesus was generally low (Fig. 3a), although higher values were calculated in Saeftinghe in May and August (0.85 and 0.64, respectively) and in Zuidgors in May (1.15). The diet diversity of D. labrax (1.07-1.81) was generally higher than of $P$. flesus, indicating a wider prey spectrum and thus a greater niche breadth (Fig. 3b). Exceptions to this occurred in May in Zwin (0.34) and in October in Zuidgors and Zwin $(0.12$ and 0.58 , respectively) but these figures were based on only $1-3$ fish stomachs.

A Kruskal-Wallis test did not reveal significant differences between the fullness indices of $P$. flesus $(P=0.13)$ caught in Saeftinghe, Waarde and Zuidgors (Table 1). Similarly there were no statistically significant differences in the fullness indices of D. labrax $(P=0.07)$ caught in the four marshes (Table 1).

The diet diversity of $P$. flesus was also tested by the non-parametric Kruskal-Wallis test and revealed a statistically significant result $(P=0.003)$. A test of multiple comparisons, which aimed to detect differences between the marshes, indicated significant differences between Saeftinghe and Waarde $(P<0.001)$ and between

Table $1 P$ values of pairwise comparisons of the FI and the Shannon-Wiener diversity indices (H') of the stomach content of $P$. flesus and D. labrax as reported by Kruskal-Wallis tests and verified by multiple comparisons

\begin{tabular}{clllll}
\hline FI & & & & & \\
P. flesus & $P=0.13$ & Saeftinghe & Waarde & Zuidgors & Zwin \\
D. labrax & $P=0.07$ & & & & \\
H' diversity index & & & & \\
P. flesus & $P=0.003$ & Saeftinghe & Waarde & Zuidgors & \\
& Waarde & $<0.001$ & - & - & \\
D. labrax & Zuidgors & 0.70 & $<0.001$ & - & \\
& $P=0.04$ & Saeftinghe & Waarde & Zuidgors & Zwin \\
& Waarde & 0.41 & - & - & - \\
& Zuidgors & 0.15 & 0.002 & - & - \\
& Zwin & 0.14 & 0.79 & 0.31 & - \\
\hline
\end{tabular}

Zuidgors and Waarde $(P<0.001)$ due to the significantly lower values in Waarde (Table 1). The Kruskal-Wallis test also showed spatial variation of stomach diversity indices of D. labrax $(P=0.04)$ and a test of multiple comparisons indicated a significantly higher diet diversity of sea bass in Waarde compared to Zuidgors $(P=0.002)$ (Table 1).

\section{Qualitative stomach analysis}

\section{Platichthys flesus}

In Saeftinghe and Zuidgors, the numerical index indicated that $89 \%$ of the diet of P. flesus consisted of $C$. volutator (Fig. 4), and similarly flounder in Waarde preyed almost exclusively upon this amphipod. In Saeftinghe and Zuigors the ragworm, $N$. diversicolor, reached a numerical percentage around $8.4 \%$. The gravimetric composition of the stomach content also showed the high dominance of these two species. In Saeftinghe and Zuidgors, $N$. diversicolor were very important in the diet (46.5 and $54.6 \%$, respectively), while in Waarde C. volutator was also the most important species in terms of biomass (78.5\%). In Saeftinghe and Zuidgors, isopods contributed 3.9 and $1.5 \%$ to the gravimetric percentage. In Zuidgors, next to the two dominant prey species, Carcinus maenas $(8 \%)$ constituted a relatively high gravimetric percentage in the diet of flounder.

Table 2 lists species which had a higher than $10 \%$ MFI and shows the dominance of $C$. volutator and $N$. diversicolor in the three marshes. The MFI of $C$. volutator ranged from $18 \%$ to $83 \%$ due to the high frequency of occurrence and the numerical dominance of this species. The MFI of $N$. diversicolor reached a maximum of $64 \%$ because of its high contribution to the weight of the stomach contents in all marshes. 
Fig. 4 Numerical (N\%) and gravimetric $(\mathrm{G} \%)$ percentages derived from the stomach analysis of $P$. flesus in the marshes of Saeftinghe, Waarde and Zuidgors in all sampled months. Number of stomachs analysed $(n)$ is indicated below each graph
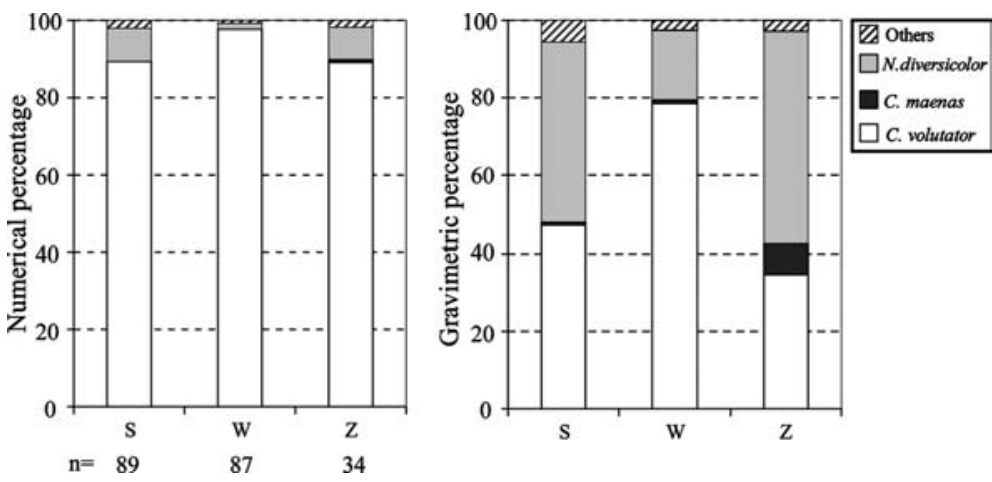

\section{Dicentrarchus labrax}

In the three brackish marshes, $C$. volutator and isopods numerically dominated the diet of the sea bass (Fig. 5). In Saeftinge, the numerical importance of $C$. volutator and isopods reached 43 and $40 \%$ respectively and $\mathrm{Or}$ chestia species also contributed $13 \%$ to the number of prey consumed there. The numerical percentage also showed the importance of $C$. volutator and isopods in Waarde (41 and 29\%, respectively) and in Zuidgors (59 and $20 \%$, respectively). In Zwin, in contrast, the typical prey items numerically were $C$. maenas $(77 \%)$ and $\mathrm{Or}$ chestia spp. $(13 \%)$.

Gravimetrically, C. maenas, C. crangon and Orchestia spp. were important in the diet of sea bass and in Saeftinhe contributed 27,18 and $28 \%$, respectively; in Waarde 57, 20 and 4\%; in Zuidgors 45, 25 and 3\%; and in Zwin 9, 32 and 55\% (Fig. 5). In Saeftinghe the biomass of $N$. diversicolor was also important in the diet of the sea bass $(11 \%)$, while in Zuidgors Mysidacea represented $9 \%$ of the biomass of the stomach content.

The MFI of the prey species of D. labrax indicated that $C$. volutator, $C$. crangon and $N$. diversicolor were the most important prey items in Saeftinghe, Waarde and Zuidgors (Table 2). The MFI of $C$. volutator was always greater than $10 \%$ because of the high $\mathrm{N} \%$ and $\mathrm{FO} \%$ values, except in August in Waarde. $N$. diversicolor was important in Saeftinghe from May till August, while in Waarde and Zuidgors the MFI was higher than $10 \%$ only in May. This pattern was due to the high gravimetric percentage of $N$. diversicolor in these months and also to the lower frequency of occurrence at the end of the sampling period. C. crangon was an important food item except in July in Saeftinghe when, due to the lower numerical percentage, the MFI did not reach the $10 \%$ threshold. The MFI of C. maenas indicated the importance of this species in July and August in Saeftinghe, Waarde and Zuidgors due to its high $\mathrm{G} \%$ and relatively

Table 2 MFI of the taxa found in the stomach of P. flesus (a) and D. labrax (b)

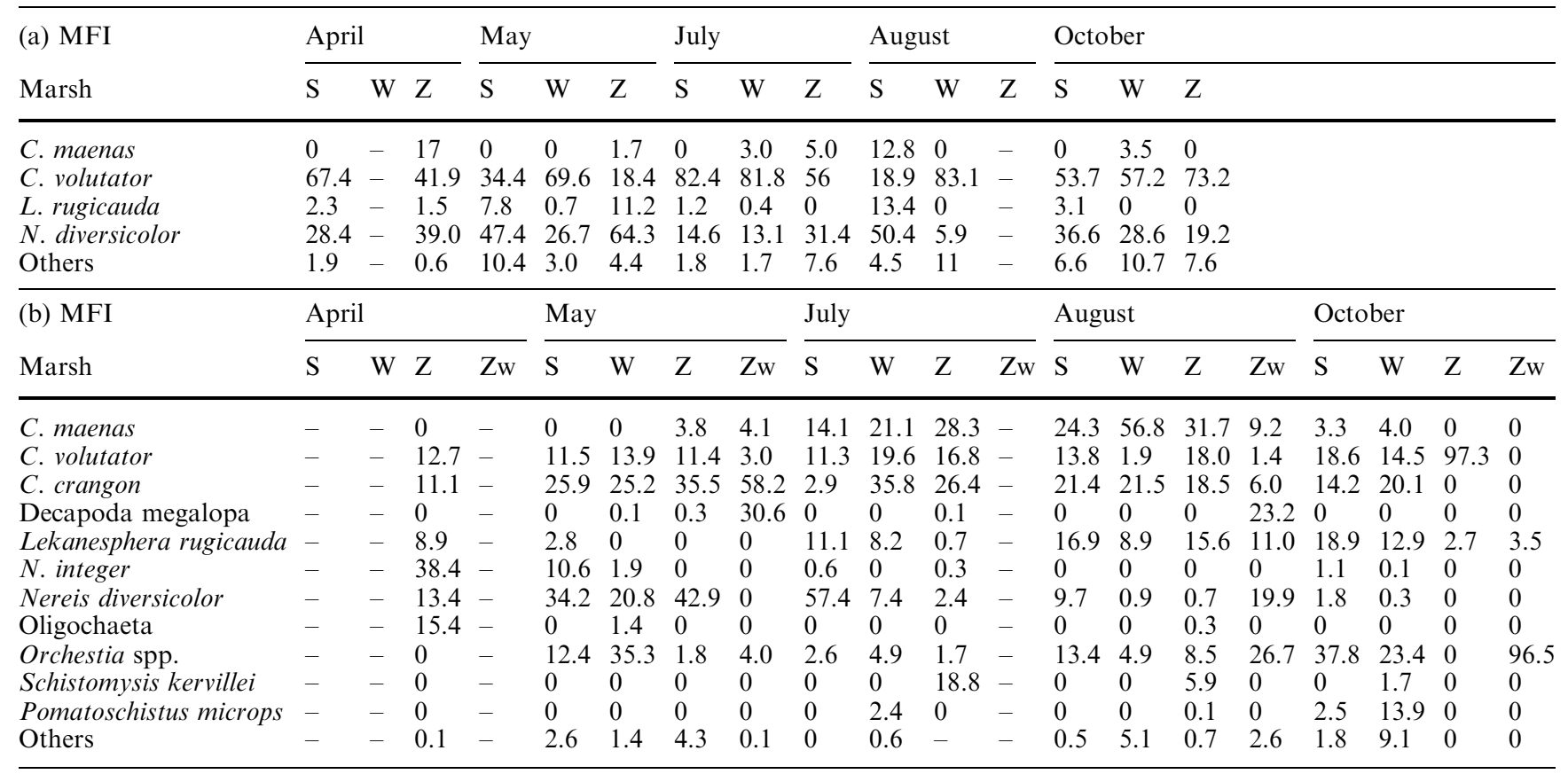

Marshes are labelled as indicated in Fig. 1 
Fig. 5 Numerical (N\%) and gravimetric $(\mathrm{G} \%)$ percentage derived from the stomach analysis of D. labrax in the marshes of Saeftinghe $(S)$, Waarde $(W)$, Zuidgors $(Z)$ and Zwin $(Z w)$ in all sampled months. Number of stomachs analysed $(n)$ is indicated below each marsh
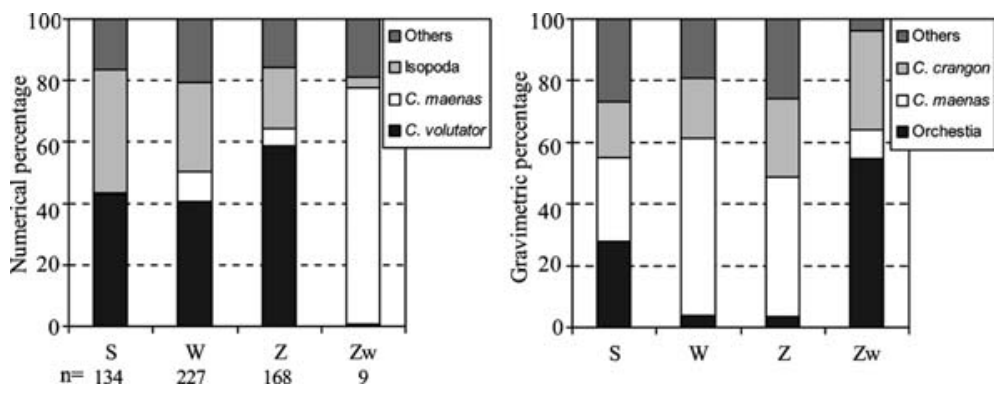

high frequency of occurrence. The isopod Lekanesphera rugicauda was important in the diet of the sea bass during the second part of the sampling period in Saeftinghe, Waarde and Zuidgors. Orchestia spp. had higher MFI values in May in Waarde and in October in Saeftinghe and Waarde. In Zwin, C. crangon, C. volutator, C. maenas, decapod megalopa larvae and Orchestia spp. reached an MFI value above $10 \%$, although caution should be exercised here because of the low number of fish analyzed.

Infaunal densities in the marsh creeks

C. volutator (16.7-8,442 ind. $\left.\mathrm{m}^{-2}\right), \quad N$. diversicolor (291.7-4,375 ind. $\mathrm{m}^{-2}$ ), Oligochaeta (771.8-22,483 ind. $\left.\mathrm{m}^{-2}\right)$, H. filiformis $\left(28-508\right.$ ind. $\mathrm{m}^{-2}$ ) and M. baltica (38.7-191.7 ind. $\mathrm{m}^{-2}$ ) had the highest average abundances in the marshes (Table 3). Species such as Eteone spp. (average 108.3 ind. $\mathrm{m}^{-2}$ ) and Pygospio elegans (58.3 ind. $\mathrm{m}^{-2}$ ) reached a maximum average density in Zuidgors, whereas Cirratulidae species (583 ind. $\mathrm{m}^{-2}$ ), Scolelepsis squamata (117 ind. $\left.\mathrm{m}^{-2}\right)$, Streblospio benedicti (192 ind. $\mathrm{m}^{-2}$ ) and Malacoceros tetraceus (308 ind. $\mathrm{m}^{-2}$ ) were still important in Zwin.

The most important benthic prey items in the diet of flounder and sea bass were $C$. volutator and $N$. diversicolor. A Spearman-Rank test did not indicate a correlation between the average monthly density and biomass of $C$. volutator and the total number of $P$. flesus in the three brackish marshes $(P=0.2$ and 0.8$)$. Neither was a correlation found between the average monthly density and biomass of $C$. volutator and the total number of $D$. labrax in Saeftinghe, Waarde, Zuidgors and Zwin $(P=0.4$ and 0.6$)$. Similarly, a lack of correlation was observed between the average density and biomass of $N$. diversicolor and the total number of flounder $(P=0.8$ and 0.6, respectively) and the total number of sea bass $(P=0.4$ and 0.2 , respectively) in the salt marshes.

Benthic stock (number and biomass) in the marsh creeks and minimum consumption by fish

The surface area of the marsh creeks was used to calculate the macrobenthic stock of the five most important prey species in the marsh channels: $17,600 \mathrm{~m}^{2}$ in Saeftinghe, $10,000 \mathrm{~m}^{2}$ in Waarde, $10,500 \mathrm{~m}^{2}$ in Zuidgors, and $9,000 \mathrm{~m}^{2}$ in Zwin. Table 4 shows the total abundance and the total biomass of the five main taxa (Oligochaeta, $C$. volutator, $N$. diversicolor, $M$. baltica, $H$. filiformis) in the four different marsh creeks for each month. The two most upstream marsh macrobenthos had their highest stock in July, reaching $2.63 \times 10^{8}$ individuals in Saeftinghe and $2.26 \times 10^{8}$ individuals in Waarde. In Zuidgors and Zwin, the macrobenthic stock was maximal in May with $4.75 \times 10^{8}$ and $1.17 \times 10^{8}$ individuals, respectively. The infaunal biomass stock was

Table 3 Average density $\left(D\right.$, ind. $\left.\mathrm{m}^{-2}\right)$ and standard error $(S E)$ of the most common benthic species found in the marsh creeks

\begin{tabular}{|c|c|c|c|c|c|c|c|c|}
\hline \multirow[t]{2}{*}{ Species } & \multicolumn{2}{|c|}{ Saeftinghe } & \multicolumn{2}{|l|}{ Waarde } & \multicolumn{2}{|l|}{ Zuidgors } & \multicolumn{2}{|l|}{ Zwin } \\
\hline & $D$ & $S E$ & $D$ & $S E$ & $D$ & $S E$ & $D$ & $S E$ \\
\hline Cirratulidae indet. & 0 & 0 & 8.3 & 8.3 & 41.7 & 17.5 & 583.3 & 269.6 \\
\hline C. volutator & $5,550.0$ & $1,590.9$ & $8,441.7$ & $1,875.6$ & $8,258.3$ & $2,041.4$ & 16.7 & 10.9 \\
\hline Eteone longa/foliosa & 0 & 0 & 16.7 & 10.9 & 108.3 & 47.0 & 41.7 & 25.0 \\
\hline H. filiformis & 41.7 & 28.0 & 191.7 & 80.1 & 508.3 & 191.0 & 325.0 & 113.7 \\
\hline M. baltica & 116.7 & 58.8 & 91.7 & 54.8 & 166.7 & 63.0 & 191.7 & 38.7 \\
\hline M. tetraceus & 0 & 0 & 0 & 0 & 0 & 0 & 308.3 & 171.8 \\
\hline N. diversicolor & $2,408.3$ & 436.9 & $2,691.7$ & 391.4 & $3,166.7$ & 291.7 & $4,375.0$ & 907.5 \\
\hline Oligochaeta indet. & $2,025.0$ & 771.8 & $3,666.7$ & $1,760.1$ & $22,483.3$ & $7,048.6$ & $5,808.3$ & $2,079.5$ \\
\hline Polydora ciliate & 0 & 0 & 0 & 0 & 8.3 & 8.3 & 41.7 & 28.0 \\
\hline P. elegans & 0 & 0 & 16.7 & 16.7 & 58.3 & 34.4 & 16.7 & 16.7 \\
\hline S. squamata & 0 & 0 & 8.3 & 8.3 & 58.3 & 42.6 & 116.7 & 51.6 \\
\hline Spio filicornis & 8.3 & 8.3 & 25.0 & 25.0 & 16.7 & 10.9 & 75.0 & 34.4 \\
\hline S. benedicti & 0 & 0 & 0 & 0 & 100.0 & 73.5 & 191.7 & 123.7 \\
\hline
\end{tabular}


estimated to reach its highest values in October in Saeftinghe $\left(14.1 \times 10^{4} \mathrm{~g} \mathrm{ADW}\right)$, and in August in the other three marshes (Waarde: $4.89 \times 10^{4}$, Zuidgors: $18.5 \times 10^{4}$, Zwin: $17.7 \times 10^{4}$ g ADW).

In general, the minimum consumption by fish from the available benthic stock was very low (Table 4). The consumption of macrobenthos by P. flesus and D. labrax was estimated to be maximal in October in Saeftinghe, Waarde and Zwin (with 0.035, 0.015 and $0.0009 \%$, respectively of the available stock) and in August in Zuidgors $(0.011 \%$ of the available density). Fish consumed the greatest amount of the available total biomass of the five benthic taxa in August in Saeftinghe and Waarde (0.014 and $0.041 \%$, respectively) and in July in Zuidgors $(0.021 \%)$. In Zwin, fish had the highest consumption of the macrobenthic biomass in October with $0.0003 \%$.

\section{Discussion}

The present study focused on the feeding of two larger predatory fish species ( $P$. flasus and D. labrax) in salt marshes to detect differences in feeding habits induced by the salinity gradient. Since the main prey items belonged to the macrobenthos, an estimation of macrobenthic food availability indicated the potential of the marsh as a feeding ground for these species. Moreover, stomach content analyses showed the presence of nursery species such as $C$. crangon, $C$. maenas or $P$. microps in the fish stomachs, and thus the nursery value of marshes for these species.

In the present study the size of flounder ranged between $130 \mathrm{~mm}$ and $250 \mathrm{~mm}$, which indicates that these individuals could have a wide spectrum of prey. Their consumption can reflect the availability of benthic species in the marsh creeks. Several previous studies have focused on the feeding habits of juvenile flounder in coastal and estuarine waters (Pihl 1982; Aarnio et al. 1996; Aarnio and Bonsdorff 1997; Mattila and Bonsdorff 1998). These showed that juveniles switch from copepods to amphipods between the size categories of 11-15 $\mathrm{mm}$ and 51-92 $\mathrm{mm}$ standard length. In the Ythan estuary in Scotland, Summers (1980) reported that flounder living on mud flats mainly consumed $C$. volutator and $N$. diversicolor and when living in areas with Mytilus edulis beds they ate $N$. diversicolor and C. maenas. In Grevelingen Lake, The Netherlands, adult flounder consumed mainly Arenicola marina, Nereis virens and Nephtys hombergii, but $C$. crangon, small C. maenas and Pomatoschistus spp. were also taken (Doornbos and Twisk 1984). Hostens and Mees (1999) reported the importance of mysids in the diet of the flounder caught in the subtidal of the Schelde estuary.

The stomach evacuation rate of $P$. flesus is estimated to be 6 to $17 \mathrm{~h}$ at $17^{\circ} \mathrm{C}$ (de Groot 1971). This suggests that the majority of the prey items found in the stomachs of flounder in the Schelde marshes originated from the tidal creek and represented the available macrobenthic 
prey in this habitat. $C$. volutator and $N$. diversicolor were clearly the most important prey for flounder foraging in the marsh creeks of the Schelde estuary, although occasionally other items such as isopods, shore crabs and shrimps were of some importance. Molluscs were also present in the fish studied here but their occurrence in the stomachs was too low to be of significance. Doornbos and Twisk (1984) also found that molluscs were rarely eaten by flounder in the Grevelingen Lake, The Netherlands. In contrast, Pihl (1982) reported that a high density of mussels resulted in a shift in the diet of young flounder from polychaetes towards bivalves in a shallow bay in Sweden. The very high densities of $C$. volutator and $N$. diversicolor in the marsh creeks in relation to other macrobenthic organisms may explain the low diet diversity of flounder foraging in these areas. In other estuarine habitats flounder were found to be opportunistic and to forage upon a wider range of prey (e.g. Elliott et al. 2002).

The present study has shown that, in the salt marshes of the Schelde, one of the main food items of sea bass was $C$. volutator. This species is easily available for predators since it reaches very high abundances in the brackish part of the estuary (Hughes 1988; Ysebaert and Herman 2002). Although C. volutator is considered a benthic species, it exhibits an intense swimming behaviour (Essink et al. 1989; Hughes 1988; Hughes and Horsfall 1990), which makes it more vulnerable for predation by D. labrax. C. crangon is also an important prey species in the estuary (Costa 1988; Cabral and Costa 2001) and in the intertidal marsh (Cattrijsse et al. 1997; Laffaille et al. 2001a). It reaches its highest abundance in the Schelde marshes between April and July (Cattrijsse et al. 1997). This coincides with the period when higher numbers of shrimp were found in the stomach of sea bass (numerical index 6-26.5\%) compared to the second half of the year (numerical index 0$7 \%$ ). The shore crab was also an important prey, and the highest densities of $C$. maenas were reported from a marsh creek of the Westeschelde between June and December (Cattrijsse et al. 1994). Sea bass also appears to be able to exploit the juvenile shore crab population since it migrates in higher numbers into the creeks when C. maenas is most abundant. Finally, C. crangon and $C$. maenas became especially important in the euhaline area where $C$. volutator is largely absent.

The feeding habits of juvenile D. labrax have been studied in estuarine habitats (Roblin and Brusle 1984; Aprahamian and Barr 1985; Kelley 1986; Hostens and Mees 1999; Cabral and Costa 2001), but only a few previous studies have considered the feeding habits of sea bass in salt marshes. Laffaille et al. (2000, 2001b) found that Neomysis integer and Orchestia gamarellus were the two major prey species of sea bass in the salt marsh of Mont Saint Michel Bay. Gardner (1996) reported the presence of $C$. crangon, $N$. diversicolor, $N$. integer and Sprattus sprattus in the diet of D. labrax in a salt marsh of the Humber estuary, although those fish were slightly larger than the ones taken in the present study. Taken together with the present findings, this indicates both the importance of small, epibenthic crustaceans in estuarine foodwebs and the ontogenetic shift of feeding preference from invertebrate to piscivorous feeding in large mobile species such as sea bass (Elliott et al. 2002). Finally, it is of relevance that the food intake of juvenile sea bass is reported to decrease rapidly at temperatures below $10^{\circ} \mathrm{C}$ and to stop at temperatures below $7^{\circ} \mathrm{C}$ (Russell et al. 1996). The sampling campaign of the present study was considered appropriate to cover the period when temperature does not restrict the foraging activity of sea bass in the marsh creeks.

The density of young individuals (Minello et al. 2003) and their feeding habits (Rozas and LaSalle 1990; Moy and Levin 1991) are both good indicators of the nursery value of a biotope. The potential of an area as a nursery partly depends upon the foraging opportunities offered by the habitat (Rozas and LaSalle 1990; Rountree and Able 1992; Craig and Crowder 2000) whereby foraging opportunity reflects both the species available, in relation to the size of predator, and their abundance (Elliott and Hemingway 2002). In the marsh creeks studied here, the densities of $C$. volutator were similar to those found in the open estuarine intertidal and subtidal areas, while the densities of $N$. diversicolor and $C$. crangon were higher (Ysebaert et al. 1993; Cattrijsse et al. 1997; Ysebaert and Herman 2002). The macrobenthos has been shown to be very abundant in the marsh creeks and so the availability of potential prey is probably not a limiting factor in the utilization of marsh creeks by fish. The minimum consumption of the larger predatory fish from the available stock was very low, indicating the high food excess in the marsh creeks and thus a high carrying capacity of the marsh areas in relation to the fish populations exploiting it. Hence, marsh creeks seem to provide good foraging opportunities for $1+$ and older flounder and sea bass, thus indicating the value of this habitat as a feeding ground. In addition to the predation by these larger fish, gobies, small sea bass and young shrimp will also add to the predation pressure on the macrobenthos when the creeks are flooded. The information about predator-prey interactions is particularly important given the ongoing creation of wetlands through depolderisation/managed realignment (McLusky and Elliott 2004).

In the Schelde marshes, it is possible that the high densities and biomass of $C$. volutator and $N$. diversicolor influence the number of flounder migrating into the creek, although no correlation was found between these factors. The lack of such a relationship may be a reflection of the excess carrying capacity as shown by the large excess of macrobenthic prey, although the low number of samples might have weakened the statistical test.

The present study has indicated spatial as well as temporal variability in the diet. Differences in the diet diversity of $P$. flesus and D. labrax from the different marshes are probably not attributable to the salinity 
gradient as no clear change in diet composition was found along the estuary. The generally limited range of prey probably precludes any shift in diet along the estuarine gradient. Despite this, spatial variations in the diet of estuarine fish may be induced by the salinity gradient (Elliott and Hemigway 2002). For example, in the Loire estuary, Masson (1987) showed that the diet of flounder shifted progressively from euhaline to oligohaline areas. In that study, Spionidae, Corophiidae and molluscs were dominant in the euhaline and polyhaline areas, while in the mesohaline zone the proportion of crustaceans increased, and copepods and chironomid larvae were abundant in the freshwater part. In the present study, the observed fullness indices of flounder and sea bass in the marshes did not show any statistical differences along the salinity gradient and hence the potential of marsh creeks as feeding grounds might be similar along the part of estuary sampled.

In the present study, the benthic prey items were present in very high abundances, and the consumption by the studied fish is considered to be too low to have a significant effect on the macrobenthic community. Predator-prey interactions can influence both predator and prey densities (Taylor 1984) and, for example, Murdoch and Oaten (1975) found that predators can stabilize the population size of their prey by switching between different prey items. In agreement with the present study, Ward and Fitzgerald (1983) also concluded that fish predation played an insignificant role in structuring the invertebrate community in Canadian saltmarsh pools, while Frid and James (1988) found that epibenthic predators in a British saltmarsh had a minimal effect on most of the infaunal species. In contrast, Reise (1978) found that, in most soft sediments, epibenthic predators are important in determining the infaunal community structure and, similarly, Joyce and Weisberg (1986) reported that Fundulus heteroclitus influenced the distribution of the marsh snail, Melampus bidentatus.

The marsh habitat studied exhibits the refuge and nursery function typical of these estuarine habitats (Elliott and Hemingway 2002). The nursery value of a marsh depends partly on the refuge that it provides against predation (Whitfield 1998; Halpin 2000; Paterson and Whitfield 2000). Hence it is of value to assess the predation pressure exerted by the larger fishes on those species using the area as a nursery or refuge, especially during their early lifecycle stages. The study of the stomach content of $P$. flesus showed that it rarely consumed C. crangon, C. maenas or Pomatoschistus microps. Similarly, the common goby was found only occasionally in the diet of sea bass despite the fact that P. microps reach peak densities in the marsh creeks in the same season as D. labrax (Cattrijsse et al. 1994). These species use the marshes as a nursery during their early lifecycle stages. The stomach analyses performed here indicate that the larger predatory fishes that use the marsh habitat as foraging grounds do not prey predominantly upon these juveniles, hence suggesting that the marsh creeks indeed offer a refuge for young year shrimp, crab and gobies.

D. labrax was generally more abundant during the second part of the sampling in August and October, and postlarvae of this species migrate into the marsh creeks in high abundances in June and July (Cattrijsse et al. 1994). This suggests some resource partitioning, that a temporal segregation in the use of the marsh creeks by postlarvae and juveniles lowers the predation risk of the younger individuals. Cattrijsse et al. (1997) reported that C. crangon reached its highest densities in the marsh creeks between May and June, whereas the present study showed that during this period $1+$ and $2+D$. labrax were present in the creeks in their lowest abundances. Again, such a temporal segregation could increase the survival of $C$. crangon in the marsh creeks. Finally, the number of shore crab consumed by sea bass did not exceed $20 \%$ of the total number of prey, which indicates that, although C. maenas is a preferred prey, sea bass is unlikely to cause sufficient mortality to affect the maintenance of the population.

In conclusion, it has been shown that the value of the marsh habitat as a nursery depends on the refuge function and the potential of the area as a feeding ground for larvae or juveniles. The investigated marsh creeks were found to act as nurseries for specific lifecycle stages of several estuarine species (Cattrijsse et al. 1994) and also to offer abundant food for the larger predatory fish. The presence of these larger fish does not appear to restrict the utilisation of the marsh creeks as a nursery by other species or younger conspecifics and, due to the abundance of the macrobenthic prey, predatory fish do not appear to have a significant impact on the macrobenthos or on the nursery species. The study implies that there is an excess carrying capacity of the marshes which is not exploited, and it shows the value of these habitats in estuarine functioning. The latter point is important given the recent development on European coasts to create similar marsh wetland areas by realigning seawalls (depolderisation/managed realignment) to aid coastal defences and create habitats (McLusky and Elliott 2004).

Declaration: The study complies with the current laws of Belgium and The Netherlands.

\section{References}

Aarnio K, Bonsdorff E (1997) Passing the gut of juvenile flounder, Platichthys flesus: differential survival of zoobenthic prey species. Mar Biol 129:11-14

Aarnio K, Bonsdorff E, Rosenback N (1996) Food and feeding habits of juvenile flounder Platichthys flesus (L.) and turbot Scophthalmus maximus L. in the Aland archipelago, northern Baltic Sea. J Sea Res 36:311-320

Aprahamian MW, Barr DC (1985) The growth, abundance and diet of O-group sea bass, Dicentrarchus labrax, from the Severn Estuary. J Mar Biol Assoc UK 65:169-180

Beyst B, Mees J, Cattrijsse A (1999) Early postlarval fish in the hyperbenthos of the Dutch Delta (south-west Netherlands). J Mar Biol Assoc UK 79:709-724 
Cabral H, Costa MJ (2001) Abundance, feeding ecology and growth of 0-group sea bass, Dicentrarchus labrax, within the nursery areas of the Tagus estuary. J Mar Biol Assoc UK 81:679-682

Cattrijsse A, Hampel H (2001) Het nekton van het Westerschelde Estuarium en het belang van schorren als habitat. Internationale Commissie voor de Bescherming van de Schelde, pp $1-35$

Cattrijsse A, Makwaia ES, Dankwa HR, Hamerlynck O, Hemminga MA (1994) Nekton communities of an intertidal creek of a European estuarine brackish marsh. Mar Ecol Prog Ser 109:195-208

Cattrijsse A, Dankwa HR, Mees J (1997) Nursery function of an estuarine tidal marsh for the brown shrimp Crangon crangon. J Sea Res 38:10-121

Costa MJ (1988) Ecologie alimentaire des poissons de l'estuaire du Tage. Cybium 12:301-320

Costa M, Catarino F, Bettencourt A (2001) The role of salt marshes in the Mira estuary (Portugal). Wetlands Ecol Manag 9:121-134

Craig JK, Crowder LB (2000) Factors influencing habitat selection in fishes with a review of marsh ecosystem. In: Weinstein MP, Kreeger DA (eds) Concepts and controversies in tidal marsh ecology. Kluwer, Dordrecht, pp 241-267

Dionne M, Short FT, Burdick DM (1999) Fish utilization of restored, created, and reference salt-marsh habitat in the Gulf of Maine. Am Fish Soc Symp 22:384-404

Doornbos G, Twisk F (1984) Density, growth and annual food consumption of plaice (Pleuronectes platessa L.) and flounder (Platichthys flesus L.) in Lake Grevelingen, the Netherlands. Neth J Sea Res 18:434-456

Elliott M, Hemingway K (2002) Fishes in estuaries. Blackwell, Oxford

Elliott M, Hemingway KL, Costello MJ, Duhamel S, Hostens K, Laropoulou M, Marshall S, Winkler H (2002) Links between fish and other trophic levels. In: Elliott M, Hemingway K (eds) Fishes in estuaries. Blackwell, Oxford, pp 124-217

Essink K, Kleef HL, Visser W (1989) On the pelagic occurrence and dispersal of the benthic amphipod Corophium volutator. J Mar Biol Assoc UK 69:11-15

Frid CLJ, James R (1988) The role of epibenthic predators in structuring the marine invertebrate community in a British coastal salt marsh. Neth J Sea Res 22:307-314

Gardner J (1996) The use of saltmarshes and adjacent intertidal mudflats as fish feeding areas. Master of Science thesis, Estuarine and Coastal Science and Management, University of Hull

Gibson RN (1994) Impact of habitat quality and quantity on the recruitment of juvenile flatfishes. Neth J Sea Res 32:191-206

Gorman M, Raffaelli D (1993) The Ythan estuary. Biologist 40:1013

de Groot SJ (1971) On the interrelationships between morphology of the alimentary tract, food and feeding behaviour in flatfish (Pisces: Pleuronectiformes). Neth J Sea Res 5:121-196

Halpin PM (2000) Habitat use by an intertidal salt-marsh fish: trade-offs between predation and growth. Mar Ecol Prog Ser 198:203-214

Hamerlynck O, Cattrijsse A (1994) The food of Pomatoschistus minutus (Pisces, Gobiidae) in Belgian coastal waters, and a comparison with the food of its potential competitor P. lozanoi. J Fish Biol 44:753-771

Hostens K, Mees J (1999) The mysid-feeding guild of demersal fishes in the brackish zone of the Schelde estuary. J Fish Biol 55:704-719

Hughes RG (1988) Dispersal by benthic invertebrates: the in situ swimming behaviour of the amphipod Corophium volutator. J Mar Biol Assoc UK 68:565-579

Hughes RG, Horsfall M (1990) Differences in the swimming behaviour of the amphipod Corophium volutator from the different populations. J Mar Biol Assoc UK 70:143-148

Hyslop EJ (1980) Stomach contents analysis - a review of methods and their application. J Fish Biol 17:411-429
Joyce AA, Weisberg SB (1986) The effects of predation by the mummichog, Fundulus heteroclitus (L.) on the abundance and distribution of the saltmarsh snail, Melampus bidentatus (Say). J Exp Mar Biol Ecol 100:295-306

Kelley D (1986) Bass nurseries on the west coast of the UK. J Mar Biol Assoc UK 66:439-464

Kneib RT (1995) Behaviour separates potential and realized effects of decapod crustaceans in salt marsh communities. J Exp Mar Biol Ecol 193:239-256

Laffaille P, Lefeuvre JC, Feunteun E (2000) Impact of sheep grazing on juvenile sea bass, Dicentrarchus labrax L., in tidal salt marshes. Biol Cons 96:271-277

Laffaille P, Lefeuvre JC, Thorin S, Feunteun E (2001a) Are young sea bass, Dicentrarchus labrax L. (Teleostei: Pisces), adapted to mussel cultures? J Mar Biol Assoc UK 81:363-364

Laffaille P, Lefeuvre JC, Schricke MT, Feunteun E (2001b) Feeding ecology of 0-group sea bass, Dicentrarchus labrax, in salt marshes of Mont Saint Michel Bay (France). Estuaries 24:116125

Lefeuvre JC, Bouchard V, Feunteun E, Grare S, Laffaille P, Radureau A (2000) European salt marshes diversity and functioning: the case study of the Mont Saint-Michel Bay, France. Wetlands Ecol Manag 8:147-161

Marshall S, Elliott M (1997) A comparison of univariate and multivariate numerical and graphical techniques for determining inter- and intra-specific feeding relationships in estuarine fish. J Fish Biol 51:526-545

Masson G (1987) Biologie et ecologie d'un poisson plat amphihaline, le flet (Platichthys flesus, Linne 1758) dans l'environnement ligerien: distribution, demographie, place au sein des reseaux trophiques. $\mathrm{PhD}$ thesis, University Brest

Mattila J, Bonsdorff E (1998) Predation by juvenile flounder (Platichthys flesus L.): a test of prey vulnerability, predator preference, switching behaviour and functional response. J Exp Mar Biol Ecol 227:221-236

McLusky DS, Elliott M (2004) The estuarine ecosystem: ecology, threats and management, 3rd edn. Oxford University Press, Oxford.

Minello TJ, Able KW, Weinstein MP, Hays CG (2003) Salt marshes as nurseries for nekton: testing hypotheses on density, growth and survival through meta-analysis. Mar Ecol Prog Ser 246:39-59

Moy LD, Levin LA (1991) Are Spartina marshes a replaceable resource? a functional approach to evaluation of marsh creation efforts. Estuaries 14:1-16

Murdoch WW, Oaten A (1975) Predation and population stability. Adv Ecol Res 9:2-131

Paterson AW, Whitfield AK (2000) Do shallow-water habits function as refugia for juvenile fishes? Estuar Coast Shelf Sci $51: 359-364$

Pickett GD (1989) The sea-bass. Biologist 36:89-95

Pihl L (1982) Food intake of young cod and flounder in a shallow bay on the Swedish West coast. Neth J Sea Res 15:419-432

Raffaelli D, Richner H, Summers R, Northcott S (1990) Tidal migrations in the flounder (Platichthys flesus). Mar Behav Physiol 16:249-260

Reise K (1978) Experiments on epibenthic predation in the Wadden Sea. Helgol Wiss Meeresunters 31:55-101

Roblin C, Brusle J (1984) Le regime alimentaire des alevins et juveniles de loup (Dicentrarchus labrax L.) des lagunes littorales du Golfe du Lion (Etangs Roussillonnais, France). Vie Milieu 34:195-207

Rountree RA, Able KW (1992) Foraging habits, growth, and temporal patterns of salt-marsh creek habitat use by young-ofyear summer flounder in New Jersey. Trans Am Fish Soc 121:765-776

Rozas LP, LaSalle MW (1990) A comparison of the diets of Gulf Killifish, Fundulus grandis Baird and Girard, entering and leaving a Mississippi brackish marsh. Estuaries 13:332-336

Rozas LP, Odum WE (1988) Occupation of submerged aquatic vegetation by fishes: testing the roles of food and refuge. Oecologia 77:101-106 
Rozas LP, Zimmerman RJ (2000) Small-scale patterns of nekton use among marsh and adjacent shallow nonvegetated areas of the Galveston Bay Estuary, Texas (USA). Mar Ecol Prog Ser 193:217-239

Russell NR, Fish JD, Wootton RJ (1996) Feeding and growth of juvenile bass: the effect of ration and temperature on growth rate and efficiency. J Fish Biol 49:206-220

Summers RW (1980) The diet and feeding behaviour of the flounder Platichthys flesus L. in the Ythan estuary, Aberdeenshire, Scotland. Estuar Coast Mar Sci 11:217-232

Taylor, RJ (1984). Predation. Chapman \& Hall, London

Walters K, Jones E, Etherington L (1996) Experimental studies of predation on metazoans inhabiting Spartina alterniflora stems. J Exp Mar Biol Ecol 195:251-265

Ward G, Fitzgerald GJ (1983) Fish predation on the macrobenthos of tidal salt marsh pools. Can J Zool 61:1358-1361

Whitfield AK (1998) Biology and ecology of fishes in southern African estuaries. Ichthyological Monographs of the J. L. B. Smith Institute of Ichthyology 2
Wiltse WI, Foreman KH, Teal JM, Valiela I (1984) Effects of predators and food resources on the macrobenthos of salt marsh creeks. J Mar Res 42:923-942

Wolff WJ, Mardos MA, Sandee AJJ (1981) Tidal migration of plaice and flounders as a feeding strategy. In: Jones NJ, Wolff WJ (eds) Feeding and survival strategies of estuarine organisms. Plenum Press, New York, pp 159-171

Ysebaert T, Herman PMJ (2002) Spatial and temporal variation in benthic macrofauna and relationships with environmental variables in an estuarine, intertidal soft-sediment environment. Mar Ecol Prog Ser 244:105-124

Ysebaert T, Meire P, Maes D, Buijs J (1993) The benthic macrofauna along the estuarine gradient of the Schelde estuary. Neth J Aqua Ecol 27:327-341

Zander CD (1982) Feeding ecology of littoral gobiid and blennoid fish of the Banyuls area (Mediterranean Sea) Main food and trophic dimension of niche and ecotope. Vie Milieu $32: 1-10$ 